\title{
PENGEMBANGAN EKONOMI LOKAL MELALUI PEMBERDAYAAN EKONOMI PEREMPUAN \\ (Studi Pada Desa Candi Renggo Kecamatan Singosari Kabupaten Malang)
}

\author{
Oleh: \\ Fitriyah, MM \\ Esy Nur Aisyah, SE., MM \\ Putri Kurnia Widiati, SE.,MM
}

\begin{abstract}
Abstrak
Singosari adalah sebuah kecamatan di Kabupaten Malang, Provinsi Jawa Timur, Indonesia. Kecamatan ini berada di sebelah utara Kota Malang, kecamatan ini dilintasi jalur utama Surabaya-Malang dan termasuk sebagai daerah titik macet terparah di Malang. Namun dari sisi SDM Singosari dapat dikataka sebagai salah satu dai urutan teratas kecamatan termaju dan paling terpandang di Kabupaten Malang. Terletak pada ketinggian 400-700 meter. DPL, Singosari beriklim sejuk. Daerah yang lebih tinggi berada di sebelah barat kaki Gunung Arjuno dimana sebagian besar wilayahnya diperuntukkan bagi perkebunan (kopi), kehutanan (mahoni) dan peternakan (ayam). Bersama dengan Lawang dan Kepanjen, Singosari dikenal sebagai kota satelit penyangga utama Kota Malang, yang termasuk dalam kawasan Malang raya

Penelitian ini merupakan jenis penelitian terapan (Applied Reseach) yaitu penelitian yang mempunyai alasan praktis, keinginan untuk mengetahui yang bertujuan agar dapat melakukan sesuatu yang lebih baik, efektif, efisien. penelitian yang dilakukan dengan tujuan untuk menerapkan hasil penemuan guna memecahkan masalah tertentu yang sedang dialami suatu organisasi. Jenis penelitian ini adalah kualitatif dengan pendekatan deskriptif.

Berdasarkan hasil analisis yang dilakukan dalam pengembangan ekonomi lokal berdasarkan sektor perdagangan dan komoditas unggulan di Desa Candirenggo Kec. Singosari diperoleh kesimpulan sebagai berikut:Komoditas unggulan sektor perdagangan di Desa Candirenggo Kec. Singosari adalah untuk subsektor tanaman bahan makanan adalah Jahe Merah. Pengembangan komoditas dapat dilakukan melalui peningkatan variasi produk hasil pengolahan untuk menciptakan nilai tambah. Disamping itu, perlu dilihat peluang pengembangan klaster industri untuk meningkatkan daya saing dari komoditas unggulan (Jahe Merah).
\end{abstract}

\section{Abstract}

Singosari is a town in Malang, East Java province, Indonesia. The subdistrict is located in the North of Malang city, district is crossed the main line of Surabaya-Malang and included as the worst jam region point in Malang. But from the human resources side, Singosari is arguably one of the most advanced sub top and most popular in Malang. Located at an altitude of 400-700 meters. Singosari district having a cool climate. Higher areas were located in Western foot of Arjuno mountain where most of its territory destined for plantations (coffee), forestry (mahogany) and livestock (chickens). Along with Lawang and Kepanjen, Singosari was known as satellite city of Malang main buffer, which is included in the area of Malang raya. 
This research is applied research (Applied Reseach) i.e. research that had practical reasons, desire to know which aims to be able to do something better, effective, efficient. Research conducted for the purpose to applying the results in order to solve a particular problem that is being experienced by an organization. This type of research is a qualitative with descriptive approach.

Based on the results of the analysis undertaken in the development of the local economy based on trade and superior commodities sector's in the village of Candirenggo Kec. Singosari, we can get the conclussion as follows: Superior commodity trading sectors in the village Candirenggo Kec. Singosari is for food crop subsector is Red Ginger. The development of commodity can be done through an increase in variation products processing to create added value. In addition, it needs to be seen to cluster industry development opportunities to enhance the competitiveness of the superior commodity (Red Ginger).

\section{I.Pendahuluan}

Pengembangan serta pembangunan wilayah diperlukan demi tercapainya peningkatan kesejahteraan rakyat serta mendorong pertumbuhan perekonomian wilayah. Menurut Direktorat Pengembangan Daerah Khusus dan Tertinggal Badan Perencanaan Pembangunan Nasional (2004), pengembangan wilayah merupakan upaya untuk memperbaiki tingkat kesejahteraan hidup di wilayah tertentu, memperkecil kesenjangan pertumbuhan dan ketimpangan kesejahteraan antarwilayah. Sembiring dan Evariani B.R. (2012) menyebutkan bahwa pengembangan wilayah merupakan strategi memanfaatkan dan mengkombinasikan faktor internal (kekuatan dan kelemahan) dan eksternal (peluang dan tantangan untuk meningkatkan produksi wilayah akan barang dan jasa. Faktor internal berupa sumber daya alam, sumber daya manusia dan sumber daya teknologi,. Sedangkan faktor eksternal berupa peluang dan ancaman yang muncul seiring interaksi yang terjadi.

Konsep Pengembangan Ekonomi Lokal (PEL) adalah salah satu strategi yang dianggap dapat menciptakan pertumbuhan eknomi dan pada saat yang sama mampu mendorong kemandirian dan ketahanan ekonomi. Melalui konsep PEL, pihak pemerintah, swasta dan masyarakat dapat saling bersinergi untuk membentuk kondisi perekonomian yang lebih baik dan menciptakan lapangan kerja. Empat aspek utama yang perlu diperhatikan dalam konsep PEL adalah sumber daya fisik, sumber daya manusia, ekonomi, dan kemitraan (Prasetyo, 2014).

Pendekatan pada pengembangan wilayah, termasuk pada konsep PEL, selalu mempertimbangkan aspek keruangan karena tiap wilayah memiliki karakteristik keruangan yang 
berbeda dan spesifik. Perbedaan karakteristik tersebut membuat kebutuhan pengembangan wilayah yang berbeda-beda pula.

Komoditi unggulan merupakan hasil usaha masyarakat yang memiliki peluang pemasaran yang tinggi dan menguntungkan bagi masyarakat. Beberapa kriteria dari komoditi unggulan adalah:

(a) Mempunyai daya saing yang tinggi di pasaran (keunikan /ciri spesifik, kualitas bagus, harga murah)

(b) Memanfaatkan potensi sumberdaya lokal yang potensial dapat dikembangkan

(c) Mempunyai nilai tambah tinggi bagi masyarakat

(d) Secara ekonomi menguntungkan dan bermanfaat untuk meningkatkan pendapatan dan kemampuan sumberdaya manusia

(e) Layak didukung oleh modal bantuan atau kredit

\section{Dasar Teori}

Pembangunan ekonomi meliputi 11 sektor produktif dalam perhitungan pendapatan nasional, yaitu sektor pertanian, industri pengolahan, pertambangan dan galian, listrik dan gas, bangunan, pengangkutan dan komunikasi, perdagangan, bank dan lembaga keuangan, sewa rumah, pertahanan, jasa lainnya (Syamsi, 2009). Keberhasilan pembangunan ekonomi suatu wilayah dapat diukur melalui beberapa indikator, seperti tinggi pertumbuhan ekonomi dan pendapatan per kapita, semakin terbukanya kesempatan kerja sehingga dapat menekan pengangguran, menurunnya jumlah penduduk yang hidup di bawah kemiskinan absolute, pergeseran struktur ekonomi kea rah yang lebih modern, dan semakin besarnya kemampuan keuangan untuk membiayai administrasi pemerintah dan kegiatan pembangunan (Soekarni dan Mahmud, 2000).

Pembangunan pedesaan sering dalam bahasa inggris disebut dengan Community Development, pembangunan masyarakat desa merupakan proses perubahan sosial yang direncanakan untuk mengubah keadaan yang tidak dikehendaki ke arah yang dikehendaki dan lebih baik. Menurut Rahardjo (2006) pembangunan masyarakat desa adalah merupakan bagian dari pembangunan nasional, secara khusus pembangunan masyarakat desa memiliki pengertian sebagai berikut:

a. Pembangunan masyarakat desa berarti pembangunan masyarakat tradisional menjadi masyarakat modern. 
b. Pembangunan masyarakat desa berarti membangun swadaya masyarakat dan rasa percaya diri sendiri.

c. Pembangunan pedesaan tidak lain dari pembangunan usaha tani atau membangun pertanian.

Pengembangan Ekonomi Lokal adalah proses partisipatori dimana semua pihak dari semua sektor di lokal tersebut bekerja bersama-sama untuk menstimulasi aktivitas komersial sehingga tercipta kondsi ekonomi yang tangguh dan berkelanjutan (UN-HABITAT, 2003). Pengembangan ekonomi lokal memiliki ciri yang utama adalah kebijakan endogenous development yang menggunakan potensi sumber daya manusia, institusi, dan sumberdaya alam (fisik) (Blakely, 1994).

\section{Profil Desa dan Keluarahan}

Singosari adalah salah satu Kecamatan di Kabupaten Malang. Luas Kecamatan Singosari secara keseluruhan sekitar $118,51 \mathrm{~km}^{2}$ atau sekitar 3,98\% dari total luas wilayah Kabupaten Malang. Candirenggo adalah sebuah kelurahan di wilayah Kecamatan Singosari, Kabupaten Malang, Provinsi Jawa Timur. Kecamatan Singosari berada di sebelah utara Kota Malang. Kecamatan ini dilintasi jalur utama Surabaya-Malang dan termasuk sebagai daerah titik macet terparah di Malang. Namun dari sisi SDM Singosari bisa dikatakan sebagai kecamatan termaju dan terpandang di Kabupaten Malang. Terletak pada ketinggian 400-700 meter dpl, Singosari beriklim sejuk. Daerah yang lebih tinggi berada di sebelah barat kaki Gunung Arjuno di mana sebagian besar wilayahnya diperuntukkan bagi perkebunan (kopi), kehutanan (mahoni) dan peternakan (ayam) sehingga populasi penduduknya jarang. Bersama dengan Lawang dan Kepanjen, Singosari dikenal sebagai kota satelit penyangga utama Kota Malang, yang termasuk dalam kawasan Malang Raya.

Desa Candirenggo merupakan salah satu Kelurahan di Kecamatan Singosari Kabupaten Malang. Desa ini benar-benar mencerminkan desa-urban, dimana dibatasi dengan desa lain, yaitu Desa Ardimulyo, Desa Pagentan, Desa Gunungrejo, dan Desa Losari. Luas wilayah desa meliputi 338,567 ha. Luas keseluruhan untuk pemukiman sebesar 149 ha, tanah sawah seluas 35 ha, dan sisaya luas untuk bangunan gedung - gedung kantor dan sebagainya. Tingkat kesuburan tanah tergolong kategori sedang, dengan curah hujan yang cukup (331 mm/tahun). 
Hasil panen padi dan palawija padi cukup produktif yaitu sekitar 125 ton gabah padi sawah dan 40 ton padi tadah hujan/ ladang denggan luas masing-masing efektif 23 ha dan 10 ton ha. Hewan peliharaan terdapat : sapi, kerbau, kuda, kambing, ayam serta itik. Khusus sapi terdapat 15 ekor sapi perah, 13 ekor sapi potong serta 15 ekor kerbau.

\section{IV.Hasil Penelitian}

Internal Factor of Analysis Strategy (IFAS) merupakan sebuah matrik evaluasi faktorfaktor internal yang memuat tentang kekuatan dan kelemahan organisasi. Setelah melakukan analisis lingkungan internal di desa Jatoarjo berdasarkan persepsi stekeholders, maka langkah akhir dari analisis ini adalah membuat matrik IFAS. Menurut David (2002) matrik IFAS dikembangkan berdasarkan lima langkah berikut, yakni; 1) Menuliskan faktor-faktor sukses kritis yang dikenali dalam proses analisis internal, 2) memberikan bobot dengan kisaran dari 0,0 (tidak penting) sampai 1,0 (terpenting) pada setiap faktor, 3) memberikan peringkat 1 sampai 4 pada setiap faktor untuk menunjukkan kepentingan relatif dari faktor itu untuk sukses dalam industri yang ditekuni, 4) mengalikan setiap bobot dengan peringkat untuk menentukan total nilai yang dibobot untuk setiap variabel, 5) menjumlah nilai yang dibobot setiap variabel untuk menentukan total nilai yang dibobot dalam organisasi.

Berikut adalah matrik IFAS tentang faktor-faktor kunci dalam analisis internal yang diperoleh melalui FGD dengan para stakeholders:

Tabel 4.1

Analisis Matrik IFAS

\begin{tabular}{|l|l|l|l|l|}
\hline \multicolumn{2}{|l|}{ Faktor-Faktor Kunci } & Bobot & Nilai & Nilai yang dibobot \\
\hline Kekuatan Internal & $\begin{array}{l}\text { Sumber daya lahan kondisi } \\
\text { geografis Desa Candirenggo. }\end{array}$ & 0,17 & 3 & 0.51 \\
\hline 2 & Sumber Daya Manusia & 0,15 & 3 & 0.45 \\
\hline 3 & Kelembagaan Masyarakat & 0,14 & 2 & 0.28 \\
\hline 4 & $\begin{array}{l}\text { Dukungan Dinas Perdagangan dan } \\
\text { Pengolahan Pangan }\end{array}$ & 0,12 & 2 & 0.24 \\
\hline 5 & $\begin{array}{l}\text { Dukungan dari Perguruan Tinggi } \\
\text { Jumlah }\end{array}$ & 0,11 & 1 & 0.11 \\
\hline Kelemahan Internal & & & $\mathbf{1 . 5 9}$ \\
\hline
\end{tabular}




\begin{tabular}{|l|l|l|l|l|}
\hline 1 & Ketersediaan modal. & 0,12 & 2 & 0.24 \\
\hline 2 & Kondisi harga hasil Produksi & 0,09 & 2 & 0.18 \\
\hline 3 & $\begin{array}{l}\text { Kesadaran Masyarakat/Pedagang } \\
\text { untuk perawatan produksi } \\
\text { (Maintenance). }\end{array}$ & 0.05 & 1 & 0.05 \\
\hline 4 & $\begin{array}{l}\text { Pedagang adalah profesi satu- } \\
\text { satunya }\end{array}$ & 1 & 0.05 \\
\hline $\begin{array}{l}\text { Jumlah } \\
\text { Total keseluruhan IFAS }\end{array}$ & $\mathbf{1}$ & $\mathbf{1 7}$ & $\mathbf{2 , 1 1}$ \\
\hline
\end{tabular}

Sumber: Data diolah

Jumlah nilai yang dibobot berdasarkan matriks IFAS sebesar 2.11. Nilai total ini masih dibawah dari nilai rata-rata (2,5). Menurut David (2002: 169) jumlah nilai yang dibobot berdasarkan matriks IFAS dapat berkisar antara 1,0 yang terendah sampai 4 yang tinggi, dengan rata-rata 2,5. Total nilai dibobot yang di bawah 2,5 merupakan kondisi yang lemah secara internal, demikian sebaliknya. Berdasarkan hasil analisis internal dan standar capainnya, Desa Candirenggo masih sangat perlu meningkatkan kualitas hasil produksi dan kekuatan internalnya.

Eksternal Factor of Analysis Strategy (EFAS) merupakan sebuah matrik evaluasi faktorfaktor eksternal yang memuat tentang peluang dan ancaman terhadap organisasi. Dalam memberikan penilaian (bobot) masing-masing faktor mulai dari 0,00 (tidak penting) sampai 1,00 (paling penting). Jumlah penilaian tidak melebihi 1,00. Sedangkan penilaian untuk rating (nilai) pada faktor peluang, jika peluangnya besar diberi nilai +4 (sangat tinggi), namun jika peluang kecil diberi nilai +1 . Penilaian yang bersifat positif dari +1 sampai dengan +4 . Namun untuk variabel yang negatif (tantangan), semakin besar tantangannya nilainya 1 dan jika semakin berpeluang (nilai di bawah rata-rata industri lain) nilainya tinggi (4) (Martono, 2004).

Berikut adalah matrik EFAS tentang faktor-faktor kunci dalam analisis eksternal yang diperoleh melalui FGD dengan para stakeholders :

Tabel 4.2

Analisis Matrik EFAS

Faktor-faktor Kunci

Bobot Nilai

Skor

Bobot 


\begin{tabular}{|c|c|c|c|c|}
\hline \multicolumn{2}{|c|}{ Peluang Eksternal } & \multirow[b]{2}{*}{0,17} & \multirow[b]{2}{*}{4} & \multirow[b]{2}{*}{0.68} \\
\hline 1 & Tingkat permintaan lokal hasil produksi. & & & \\
\hline 2 & $\begin{array}{l}\text { Ketersediaan Infrastruktur yang memadai } \\
\text { seperti jalan, listrik dan juga air }\end{array}$ & 0,17 & 3 & 0.51 \\
\hline 3 & $\begin{array}{l}\text { Adanya investor swasta yang tertarik } \\
\text { berinvestasi untuk pengembangan olahan } \\
\text { produk lokal }\end{array}$ & 0,10 & 3 & 0.30 \\
\hline 4 & Terbukanya pasar ASEAN tahun 2015 & 0,15 & 3 & 0.45 \\
\hline \multicolumn{2}{|c|}{ Total } & & & 1.94 \\
\hline \multicolumn{2}{|c|}{ Ancaman Eksternal } & & & \\
\hline 1 & $\begin{array}{l}\text { Perkembangan kondisi agroklimat dimana } \\
\text { curah hujan tinggi akan menyebabkan } \\
\text { turunnya priduktivitas dan kualitas hasil } \\
\text { produksi. }\end{array}$ & 0,10 & 2 & 0.20 \\
\hline 2 & Desiminasi Teknologi & 0,15 & 2 & 0.30 \\
\hline 3 & $\begin{array}{l}\text { Terbukanya pasar ASEAN tahun } 2015 \\
\text { sehingga produk dari Negara Asean akan } \\
\text { mudah masuk ke dalam pasar Indonesia }\end{array}$ & 0.10 & 2 & 0.10 \\
\hline 4 & $\begin{array}{l}\text { Pedagang asing yang telah memiliki rantai } \\
\text { pasok yang lebih baik sehingga mereka lebih } \\
\text { efisien dalam harga }\end{array}$ & 0,06 & 1 & 0.06 \\
\hline \multicolumn{2}{|c|}{ Total } & & & 0.66 \\
\hline \multicolumn{2}{|c|}{ Total keseluruhan EFAS } & 1,00 & 19 & 2.60 \\
\hline
\end{tabular}

Berdasarkan hasil analisis SWOT tersebut maka rencana strategis yang perlu dibuat dalam rangka pengembangan ekonomi lokal sektor perdagangan di Desa Candirenggo Kec. Singosari adalah :

1. Pengembangan wilayah potensial pertanian sebagai pusat-pusat kegiatan pertanian sesuai komoditas unggulannya.

2. Diversifikasi Olahan hasil produksi.

3. Optimalisasi infrastruktur yang telah tersedia sebagai sarana untuk penguatan interaksi dengan wilayah sekitar guna memperluas pangsa pasar. 
4. Membuka kerjasama dengan wilayah lain, khususnya yang membutuhkan pasokan bahan baku komoditas.

\section{V.Kesimpulan}

Berdasarkan hasil analisis yang dilakukan dalam pengembangan ekonomi lokal berdasarkan sektor perdagangan dan komoditas unggulan di Desa Candirenggo Kec. Singosari diperoleh kesimpulan sebagai berikut:

a) Komoditas unggulan sektor perdagangan di Desa Candirenggo Kec. Singosari adalah untuk subsektor tanaman bahan makanan adalah Jahe Merah.

b) Pengembangan komoditas dapat dilakukan melalui peningkatan variasi produk hasil pengolahan untuk menciptakan nilai tambah. Disamping itu, perlu dilihat peluang pengembangan klaster industri untuk meningkatkan daya saing dari komoditas unggulan (Jahe Merah).

c) Strategi dalam pengembangan komoditas unggulan tanaman pangan dan perkebunan adalah:

- Pengembangan wilayah potensial pertanian sebagai pusat-pusat kegiatan pertanian sesuai komoditas unggulannya.

- Diversifikasi Olahan hasil pertanian.

- Optimalisasi infrastruktur yang telah tersedia sebagai sarana untuk penguatan interaksi dengan wilayah sekitar guna memperluas pangsa pasar.

- Membuka kerjasama dengan wilayah lain, khususnya yang membutuhkan pasokan bahan bibit Jahe Merah.

\section{Saran}

Berdasarkan hasil analisis dan pembahasan terkait dengan pengembangan ekonomi lokal berdasarkan sektor perdagangan dan komoditas unggulan di Desa Candirenggo Kec. Singosari, maka dengan ini diajukan beberapa saran sebagai berikut:

1. Untuk peningkatan produksi dan kualitas hasil pertanian, saran pengembangannya adalah dalam hal pengelolaan lahan tersebut dilakukan oleh kelompok tani bekerja sama dengan pedagang di dukung oleh dinas terkait dan perguruan tinggi sebagai pihak yang independen.

2. Pemerintah daerah bekerjasama dengan pihak Perguruan Tinggi untuk mendorong pihak swasta, petani, dan pedagang agar membuat sistem informasi pasar produk pertanian 
yang terintegrasi sehingga pelaku usaha hasil produksi dapat menjalankan usahanya lebih efisien dan berdaya saing tinggi.

\section{DAFTAR PUSTAKA}

Arsyad, 2010, Konservasi Tanah dan Air, IPB Press, Bogor.

Dillon. 2004. Pertanian membangun bangsa. Jakarta: Penebar Swadaya

Moleong, Lexy, 2006. Metodologi Penelitian Kualitatif, Edisi Revisi, Penerbit PT Remaja Rosdakarya, Bandung.

Prasetyo, Rusyidi Huda. 2014. Pengembangan Klaster Industri Pengolahan Jagung Kecamatan Merakurak Kabupaten Tuban Dengan Pendekatan Pengembangan Ekonomi Lokal (PEL). Surabaya: ITS.

Rahardjo Adisasmita, . 2006. Pembangunan Pedesaan dan Perkotaan. Yogyakarta: Graha. Ilmu.

Rangkuti, F. 2005. Analisis SWOT Teknik Membedah kasus Bisnis Reorientasi Konsep Perencanaan Strategis untuk Menghadapi Abad 21, PT. Gramedia Pustaka Utama, Jakarta.

Sanjaya, Rudi. 2008. Perspektif penerapan penelitian dan pengembangan (litbang) dalam penyelenggaraan pemerintah daerah. www.Google.co.id/gwt/x?site=universal\&q. diakses tanggal 16 Maret 2015.

Sembiring, Evariani B.R. 2012. Analisis Dampak Peningkatan Jalan Desa Kuta Rayat Kecamatan Naman Teran Kabupaten Karo terhadap Pengembangan Wilayah. Medan: USU.

Soekarni dan Mahmud. 2000. Studi kelayakan ekonomi pembentukan propinsi bari: kasus Banten. Jurnal Ekonomi dan Pembangunan (JEP) Volume VII.

Surahman dan Sturisno, 1997. Pembangunan pertanian. Surakarta: UNS

Suryana. 2000. Ekonomi pembangunan problematika dan pendekatan. Jakarta: salemba Empat.

Susilowati, Iva. 2009. StrategiPengembangan Sektor Pertanian di Kabupaten Sukoharjo (Pendekatan Tipologi Klassen). Fakultas Pertanian Universitas Sebelas Maret. Surakarta.

Syamsi, Nur. 2009. Pengembangan ekonomi dan pertumbuhan ekonomi.http://jnursyamsi.staff.gunadarma.ac.id/.

Tarigan, Robinson, 2004. Perencanaan pembangunan wilayah. Jakarta: PT Bumi A' 
Wilda Al Aluf. 2014. Pengembangan Komoditas Unggulan Tanaman Pangan melalui Pendekatan Pengembangan Ekonomi Lokal di Kabupaten Pamekasan. Jurnal 
